\title{
Improving selection in south eastern Australian whiting (Sillago spp.) trawls: effects of modifying the body, extension and codend*
}

\author{
MATT K. BROADHURST, DAMIAN J. YOUNG, CHARLES A. GRAY and \\ MICHAEL E.L. WOODEN
}

NSW Department of Primary Industries, Fisheries Conservation Technology Unit, National Marine Science Centre, PO Box J321, Coffs Harbour, NSW 2450, Australia. E-mail: mbroadhurst@nmsc.edu.au.

\begin{abstract}
SUMMARY: In response to a shift towards directed targeting of whiting, Sillago spp. by some penaeid trawlers in coastal waters off New South Wales, Australia, 3 experiments were done to examine the effects on the size and species selectivity of trawls associated with (i) a $40 \%$ increase in mesh size used in the body, (ii) altering the configuration of mesh in the codend, and (iii) a separating grid in the extension section. Each experiment involved paired comparisons between conventional and modified gears during normal commercial fishing operations. The results showed that increasing mesh size in the trawl body from 45 to $63 \mathrm{~mm}$ had no effect on any catches and, while the grid has the potential to improve species selection by excluding macrofauna, further refinement and testing are required to minimize the escape of commercial sized whiting. Changing the orientation of mesh in the codend from diamond- $(40 \mathrm{~mm}$ mesh opening) to square-shaped $(41 \mathrm{~mm}$ mesh, hung on the bar) had a highly significant effect on the size selection of red spot whiting, Sillago flindersi: reducing the catches of small, unwanted individuals (<17 cm total length) by up to $99 \%$, with minimal impact on the retention of larger, commercial sized individuals. We conclude that the use of square-mesh codends (with a bar length approaching $20 \mathrm{~mm}$ ) by trawlers targeting whiting is an appropriate management tool for minimizing the fishing mortality of juvenile and maturing conspecifics.
\end{abstract}

Keywords: bycatch reduction, trawling, selectivity, Sillago robusta, Sillago flindersi.

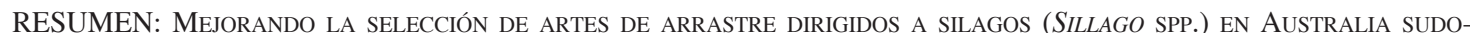
RIENTAL: EFECTOS DE LA MODIFICACIÓN DEL CUERPO, EXTENSIÓN Y COPO. - En respuesta a un cambio dirigido a la captura de silagos (Sillago spp.) por parte de algunos arrastreros camaroneros en aguas costeras de New South Wales, Australia, se realizaron tres experimentos para examinar los efectos sobre la selectividad de tallas y especies de artes de arrastre asociados con (i) un $40 \%$ de aumento en la longitud de malla utilizada en el cuerpo, (ii) alterando la configuración de la malla en el copo, y (iii) utilizando una rejilla de separación en la sección de extensión. Cada experimento constó de comparaciones pareadas entre los artes convencionales y pareados durante operaciones pesqueras comerciales normales. Los resultados mostraron que el aumento en la longitud de malla en el cuerpo del arte de 45 a $63 \mathrm{~mm}$ no tenía efecto en las capturas y que, mientras que la rejilla separadora tiene el potencial de mejorar la selección de especies por la exclusión de macrofauna, se requieren más experimentos y refinamiento para minimizar el escape de silagos de talla comercial. Cambiando la orientación de la malla en el copo desde una forma de diamante (romboidal) de $40 \mathrm{~mm}$ a una forma de malla cuadrada de $41 \mathrm{~mm}$ (colgada en la barra) tenía un efecto altamente significativo sobre la selección de tallas de silago de Flinders, Sillago flindersi: reduciendo las capturas de ejemplares pequeños, no deseados $(<17 \mathrm{~cm}$ longitud total) hasta un $99 \%$, con un impacto mínimo sobre la retención de individuos de tallas superiores, comerciales. Se concluye que el uso de copos con malla cuadrada (con una longitud de barra cercana a $20 \mathrm{~mm}$ ) por los arrastreros que tienen a los silagos como especie objetivo es una herramienta apropiada de gestión para la minimización de la mortalidad pesquera de juveniles e individuos en maduración.

Palabras clave: reducción de capturas acompañantes, arrastre, selectividad, Sillago robusta, Sillago flindersi. 


\section{INTRODUCTION}

In oceanic waters off northern New South Wales (NSW), Australia, up to 280 vessels tow smallmeshed (40-50 mm stretched mesh opening) triplerigged otter trawls at night, mostly targeting eastern king prawns, Penaeus plebejus. Like nearly all prawn-trawl fisheries throughout the world, in addition to the targeted species, trawlers in NSW catch a diverse assemblage of non-target organisms (collectively termed 'bycatch' - for reviews see Andrew and Pepperell, 1992; Alverson et al., 1994). While the majority of bycatch, including juveniles of commercially and recreationally important species, is discarded at sea, individuals comprising more than 85 species of commercially important teleosts, cephlopods and crustaceans are legally retained for sale (termed 'byproduct') (Kennelly et al., 1998).

The byproduct from oceanic trawlers in NSW is economically important, contributing more than $65 \%$ of the total landed catch (by weight) and up to $30 \%$ of the value of the fishery (approx. \$A30 m per annum) (Kennelly et al., 1998). Of the byproduct species landed and sold, red spot Sillago flindersi and stout whiting, S. robusta (typically longer than $17 \mathrm{~cm}$ total length - TL and collectively sold as 'school' whiting) have traditionally dominated catches. In recent years, owing to improved local and international markets, the retained catches of whiting have substantially increased (from approx. $600 \mathrm{t}$ in 1999 to $1100 \mathrm{t}$ in 2003) and for some trawl operators, they have replaced eastern king prawns as the main target species.

The relative importance of whiting to a few fishers has precluded attempts to mandate an appropriate and effective bycatch reduction device (BRD), termed the composite square-mesh panel (Broadhurst and Kennelly, 1996), throughout the entire fishery. This BRD comprises strategically located panels of 2 different sizes of mesh $(45 \mathrm{~mm}$ and between 60 and $150 \mathrm{~mm}$ ) hung on the bar (i.e. square shaped) and was specifically developed to allow small unwanted fish (especially juvenile whiting) to escape from codends, with no concomitant loss of eastern king prawns (Broadhurst and Kennelly, 1996; 1997). But, when rigged in the most effective configuration (i.e. using mesh $>90 \mathrm{~mm}$ hung on the bar), the composite square-mesh panel also allows the majority of commercial sized whiting to escape.

The lack of a mandatory BRD that effectively reduces unwanted bycatches throughout the oceanic trawl fishery culminated in a recent proposal to delineate between targeted fishing for eastern king prawns and whiting using distinct and appropriately configured trawls (within a triple-rig configuration) that maximize the respective targeted catches while minimizing unwanted bycatches. For fishers targeting whiting, trawls ideally should retain only commercial sized stout and red spot whiting (i.e. $\geq 17$ $\mathrm{cm}$ TL) and allow the majority of all other organisms to escape. Our objectives in this study were to provide a first step towards developing selective whiting gear by investigating the effects of simple modifications to key components of existing trawls. Specifically, we examined (i) a $40 \%$ increase in the size of mesh used in the trawl body, (ii) a change in the configuration of mesh (from conventional diamond- to square-shaped) used in the codend and (iii) using a separating grid in the extension section (i.e. between the trawl body and codend).

\section{MATERIALS AND METHODS}

Three experiments were done between August 2003 and March 2004 on trawl grounds east of Forster $\left(32^{\circ} 15^{\prime} \mathrm{S}\right.$ and $\left.152^{\circ} 30^{\prime} \mathrm{E}\right)$ in New South Wales, Australia using two commercial trawlers (14 and $16 \mathrm{~m}$ in length). Both vessels were fitted with three trawls in a standard triple-rig configuration (see Kennelly et al., 1993 for details), but, because the middle trawls were rigged differently, only the two identical outside trawls were used in the experiments. To facilitate attachment between the outside trawl bodies and codends, zippers (Buraschi S146R, $2 \mathrm{~m}$ in length) were secured at their posterior and anterior ends, respectively. All trawls were towed at approx. $1.2 \mathrm{~ms}^{-1}$ across a combination of sand and mud bottoms in depths ranging from 18 to $55 \mathrm{~m}$.

\section{Experiment 1: effects of changing mesh size in the trawl body}

Two 4-seam trawl bodies, attached to conventional codends, were used. The trawl bodies (termed the 45 and $63 \mathrm{~mm}$ bodies) had exactly the same conventional design in terms of their headline length $(11 \mathrm{~m})$, rigging, tapers, hanging ratios and twine colour (blue), material (twisted polyethylene -PE) and diameter (ș $-1.2 \mathrm{~mm}$ ) (Fig. 1), but were made from 45 and $63 \mathrm{~mm}$ mesh, (all mesh sizes refer to stretched mesh opening), respectively (Fig. 1). The codends were identical and the same as convention- 


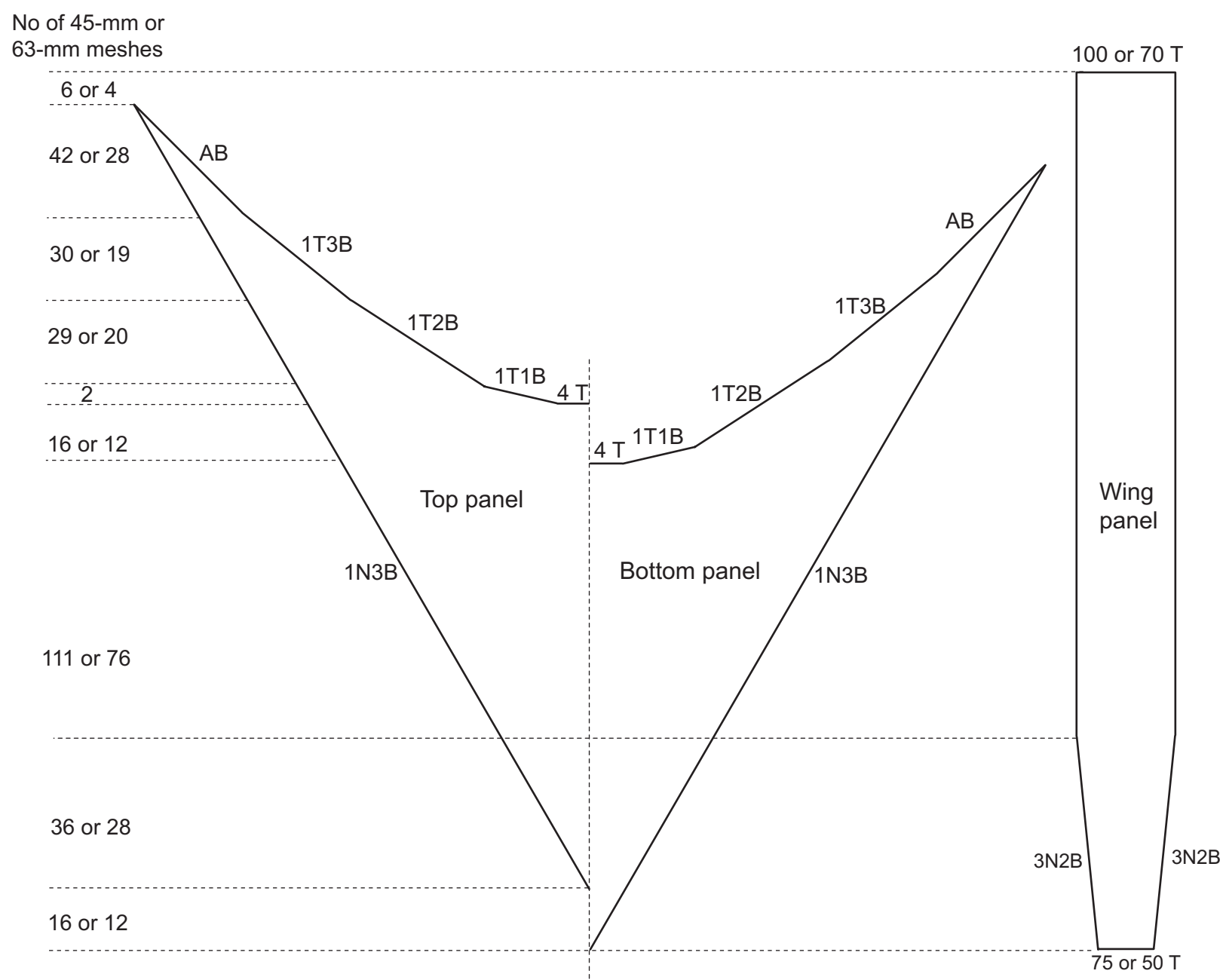

FIG. 1. - Plans of the 4-seam 45 and 63 mm net bodies used in the experiments. T, transversals; N, normals; B, bars.

al designs, comprising anterior $(150 \mathrm{~T} \times 50 \mathrm{~N})$ and posterior (200 T x $33 \mathrm{~N}$ ) sections made from $40 \mathrm{~mm}$ diamond-shaped mesh ( $2 \mathrm{~mm}$ ș, twisted PE twine) with a total length of approx. $3.8 \mathrm{~m}$ (Fig. 2A).

The decision to use $63 \mathrm{~mm}$ mesh in the trawl body was based on the expected lateral mesh openings (i.e. up to $30 \%$ of the mesh size) in the posterior section (Broadhurst et al., 1999), and the morphologies of red spot and stout whiting. In previous work, linear relationships between TL $(\mathrm{mm})$ and maximum height (MH), width (MW) and girth (MG) were calculated separately for male and female red spot ( $\mathrm{n}=81$ and 82 , respectively; $14-24$ $\mathrm{cm} \mathrm{TL})$ and stout whiting $(\mathrm{n}=108$ and 79 , respectively; 17-27 cm TL) (Koen Dykstra, unpublished data). No sexual dimorphism was demonstrated for red spot whiting (ANCOVA, $P>0.05$ ) and common regressions were calculated as: $\mathrm{TL}(\mathrm{mm})=$ 6.0809MH - 7.3209 $\left(\mathrm{r}^{2}=0.90\right) ; \mathrm{TL}=7.6071 \mathrm{MW}+$ $18.246\left(\mathrm{r}^{2}=0.88\right) ;$ and $\mathrm{TL}=2.086 \mathrm{MG}+6.3135\left(\mathrm{r}^{2}\right.$ $=0.95)$. For stout whiting, differences were detected between sexes for the relationships between TL and the parameters examined: TL males $=4.4633 \mathrm{MH}+$ $46.193\left(\mathrm{r}^{2}=0.80\right)$; TL males $=5.741 \mathrm{MW}+59.308$ $\left(\mathrm{r}^{2}=0.78\right)$; TL males $=1.6509 \mathrm{MG}+46.415\left(\mathrm{r}^{2}=\right.$ $0.84)$; $\mathrm{TL}$ females $=5.1071 \mathrm{MH}+35.198\left(\mathrm{r}^{2}=0.79\right)$; $\mathrm{TL}$ females $=5.1071 \mathrm{MW}+33.680\left(\mathrm{r}^{2}=0.87\right)$; and $\mathrm{TL}$ females $=1.9431 \mathrm{MG}+26.420\left(\mathrm{r}^{2}=0.83\right)$. These various relationships indicate that at the smallest commercial size (i.e. $17 \mathrm{~cm}$ TL), red spot whiting have a maximum height, width and girth of approx. 29,20 and $78 \mathrm{~mm}$, respectively, while for stout whiting these variables are approx. 26 to 28,19 to 20 and 74 to $75 \mathrm{~mm}$, respectively. We hypothesized that during fishing, the $63 \mathrm{~mm}$ mesh in the trawl body would have maximum lateral and diagonal mesh openings of approx. 19 and $60 \mathrm{~mm}$, respectively; sufficient to allow nearly all small whiting to escape, but retain most of the commercial sized individuals.

Each of the trawl bodies with the conventional codends attached was randomly assigned as an outside trawl on the $14 \mathrm{~m}$ trawler. We alternated trawl 
A

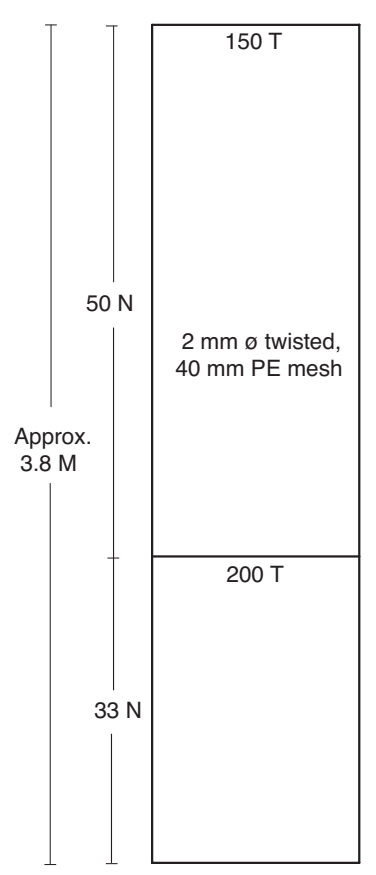

B

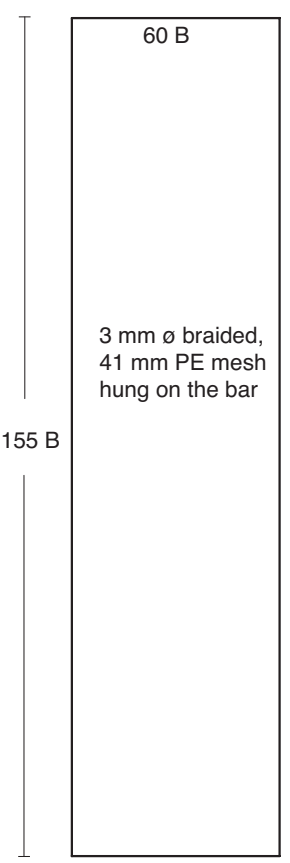

C

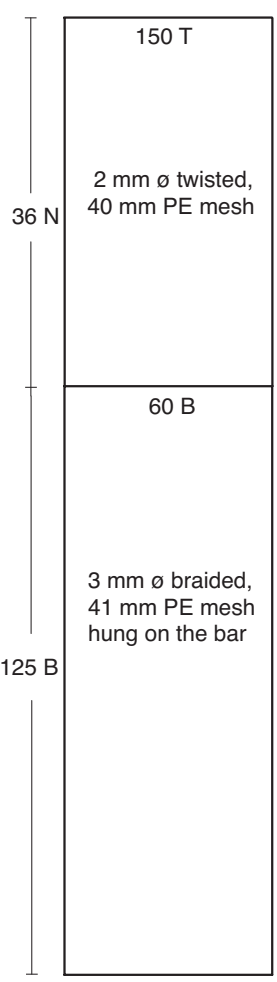

D

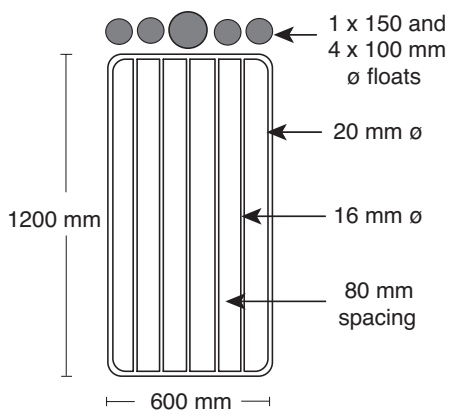

FIG. 2. - Plan of the A) conventional $40 \mathrm{~mm}$ diamond codend, B) $41 \mathrm{~mm}$ square codend, C) extension and $41 \mathrm{~mm}$ square codend, and D) alu minium grid. T, transversals; N, normals; B, bars; ș, diameter; PE, polyethylene.

bodies (on either side) at the start of each night and completed 13 replicate, paired 60 min hauls over 3 nights.

\section{Experiment 2: effects of a change in mesh con- figuration in the codend}

Two identical conventional 4-seam trawl bodies, a conventional $40 \mathrm{~mm}$ diamond-mesh codend (from above; Fig. 2A) and a square-mesh codend (Fig. 2B) were used in this experiment. The trawl bodies were made from $45 \mathrm{~mm}$ mesh (2-mm ș, twisted PE twine) and had the same design as above, but a longer head line $(16 \mathrm{~m})$. They were attached as the outside nets of the $16 \mathrm{~m}$ trawler. The square-mesh codend (termed the $41 \mathrm{~mm}$ square codend) was made entirely of $41 \mathrm{~mm}$ PE mesh (3-mm ș, braided twine) hung on the bar (i.e. bar length of $20.5 \mathrm{~mm}$ ) (Fig. 2B). This mesh size and material was used because it was the most readily available and corresponded to the appropriate transverse morphology of commercial sized red spot whiting (see above).

We randomly and alternately zippered the diamond and square-mesh codends to each of the identical trawl bodies and completed 12 replicate, 70 min paired hauls over two consecutive nights.

\section{Experiment 3: effects of a separating grid in the extension}

Two identical conventional trawl bodies (made from $45 \mathrm{~mm}$ mesh; $2 \mathrm{~mm}$ s, twisted PE twine), a conventional $40 \mathrm{~mm}$ diamond and 2 square-mesh codends, each attached to extension sections with and without a grid installed, were used in experiment 3. The $40 \mathrm{~mm}$ diamond codend had the same posterior section as that used in experiments 1 and 2 (Fig. 2A), but an anterior section that was $15.5 \mathrm{~N}$ longer (i.e. a total length of $4.6 \mathrm{~m}$ ). The $41 \mathrm{~mm}$ square codends each measured 125 x 60 B (Fig. 2C) and were shorter than that used during experiment 2 . Two extension sections made from $40 \mathrm{~mm}$ diamond-shaped mesh (2 $\mathrm{mm}$ ș, twisted PE twine - $150 \mathrm{~T} \times 36 \mathrm{~N}$ ) were attached to the anterior edges of the $41 \mathrm{~mm}$ squaremesh codends (for a total length of approx. $4.6 \mathrm{~m}-$ the same as the $40 \mathrm{~mm}$ diamond codend) (Fig. 2C). An aluminium grid (1200 x 600 mm; Fig. 2D) with $80 \mathrm{~mm}$ gaps between the bars was installed at an angle of $30^{\circ}$ into one of the extension sections (Fig. 3 ). Five floats were secured to the top of the grid and an escape exit $(36 \mathrm{~T})$ cut transversally along the bottom edge (Fig. 3). A $40 \mathrm{~mm}$ PE mesh cover (52 T x $36 \mathrm{~N}$ ) was attached anterior to the escape exit (dis- 
tance of $16 \mathrm{~N}$ ) so that it blocked the escape exit during fishing, but still allowed organisms wider than the bar spacings to push their way out of the extension (Fig. 3). The second extension section had no grid installed (Fig. 2C).

Using the $14 \mathrm{~m}$ vessel, the $41 \mathrm{~mm}$ square codend, with and without the grid installed in the extension section was alternately compared against the conventional $40 \mathrm{~mm}$ diamond codend. All codends were randomized between sides of the paired gear. On each night, we did 3 replicate, paired tows of each configuration against the conventional trawl and completed 9 replicate hauls over 3 nights.

\section{Data collected and statistical analyses}

At the end of each haul, the codends were emptied onto a partitioned tray and the following data recorded: the number and weight of total whiting; the numbers and weights of total, retained (defined as $\geq 17 \mathrm{~cm}$ TL) and discarded (defined as $<17 \mathrm{~cm} \mathrm{TL}$ ) red spot whiting and a subsample (up to 150 per tow selected from the entire catch) of their TLs (to the nearest 0.5 $\mathrm{cm}$ ); the weights of total discards (defined as bycatch discarded at sea) and byproduct (defined as bycatch retained for sale); and the numbers of all commercially important byproduct species.

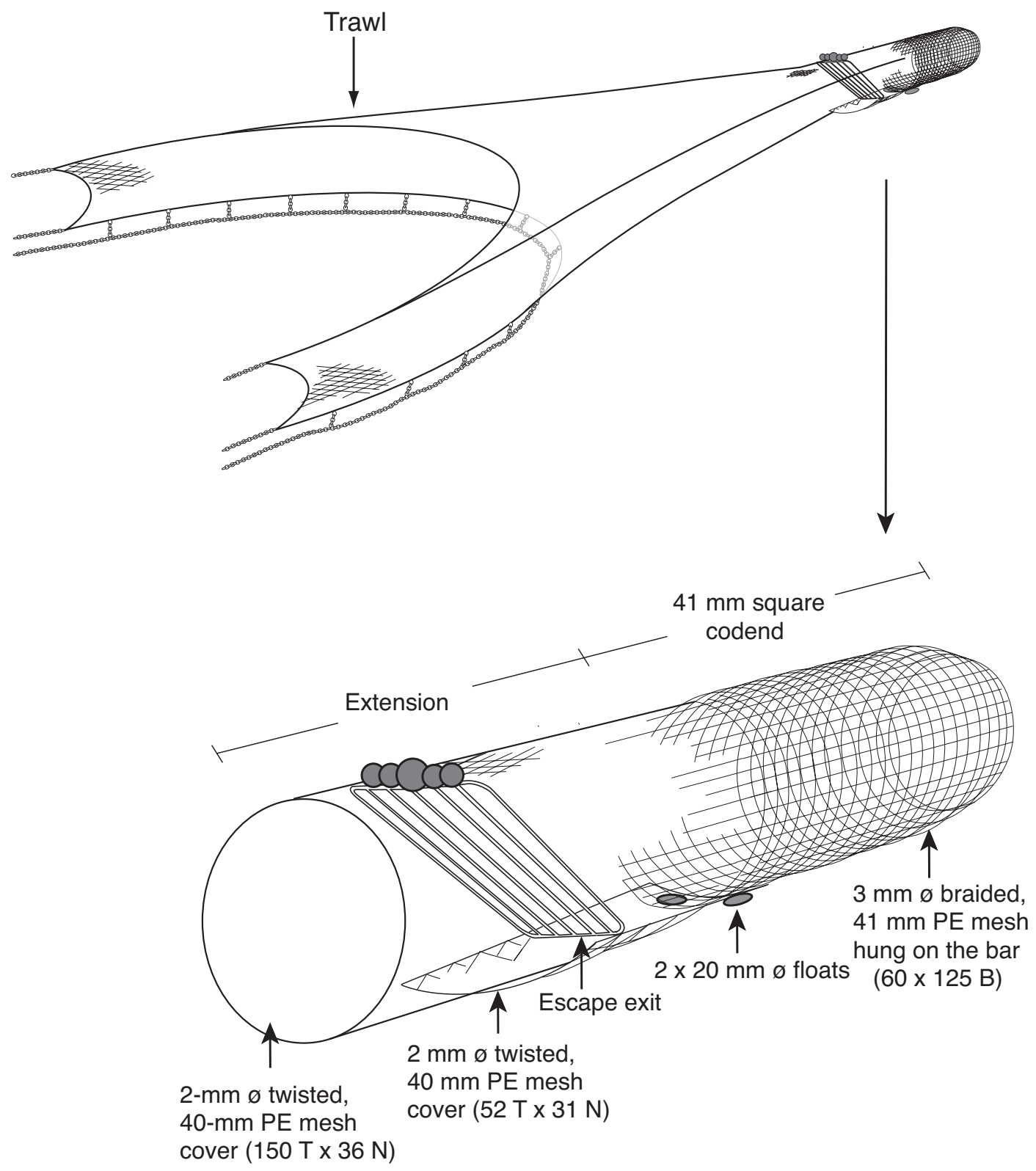

FIG. 3. - The completed whiting trawl with the grid extension and the $41 \mathrm{~mm}$ square codend attached. T, transversals; N, normals; B, bars; Ș, diameter; PE, polyethylene. 

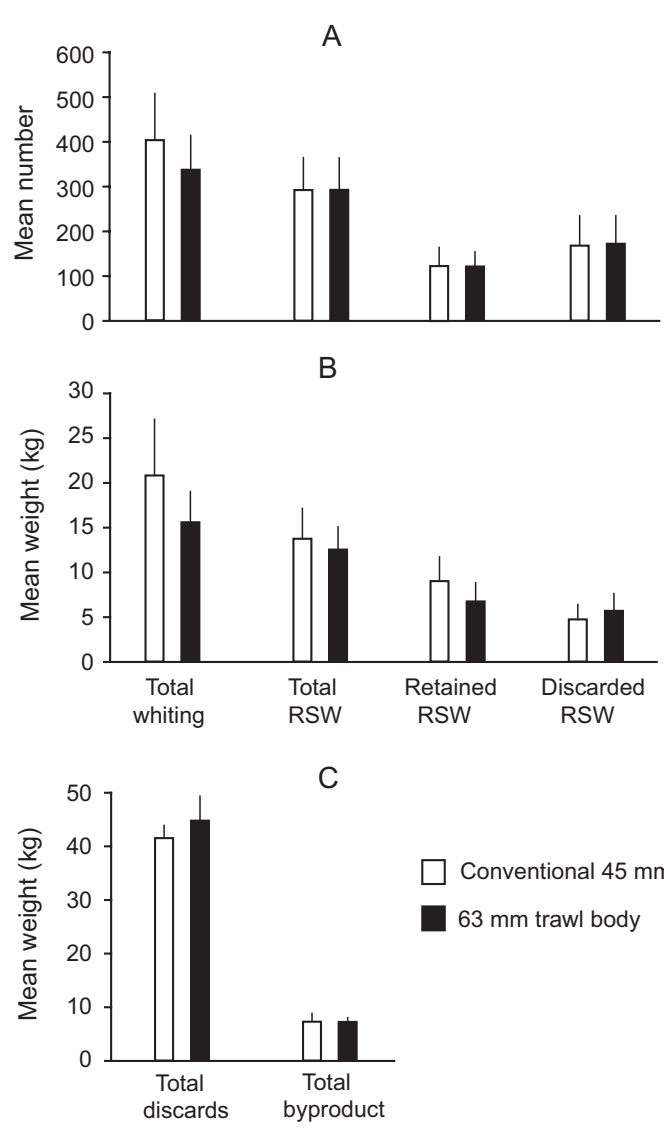

Conventional $45 \mathrm{~mm}$ trawl body

$63 \mathrm{~mm}$ trawl body

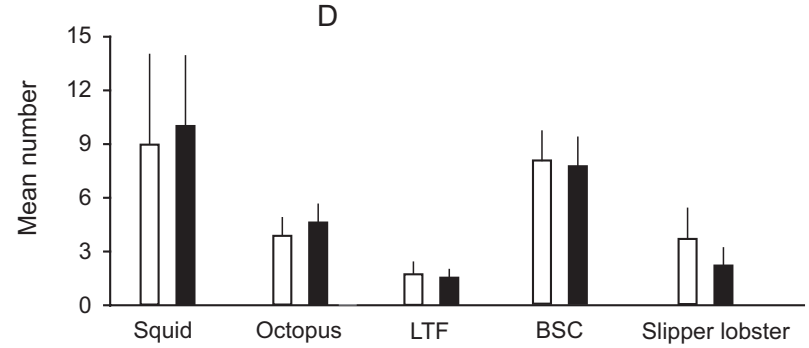

FIG. 4. - Differences in mean catch $(+\mathrm{se})$ per 75 min tow between the conventional 45 and $63 \mathrm{~mm}$ trawl bodies (same $40 \mathrm{~mm}$ diamond-mesh codend) for the A) numbers and B) weights of whiting categories, C) weights of total discards and byproduct, and D) numbers of key byproduct species. RSW, red spot whiting; LTF, largetoothed flounder; BSC, blue swimmer crab; no significant differences were detected (paired $t$-tests).

In all experiments, where there were sufficient data for variables (at least 2 individuals in 8 replicate tows), these were analysed with two-tailed, paired $t$-tests. In experiment 3 , the differences in catches between the $41 \mathrm{~mm}$ square codend, with and without the grid installed, and the conventional 40 $\mathrm{mm}$ diamond codend were $\ln \left(\mathrm{x}+10^{2}\right.$ or $\left.10^{3}\right)$ transformed, tested for heteroscedasticity using Cochran's test and analysed in an appropriate twofactor analysis of variance (ANOVA). Codends and nights were considered random and fixed factors, respectively. In each experiment, size-frequency data for red spot whiting were combined across all tows for the various treatment and conventional gears and where there were sufficient numbers (> 100 individuals in each tow), compared with two sample Kolmogorov-Smirnov tests. In all analyses, the null hypothesis was rejected at $P<0.05$.

\section{RESULTS}

Red spot whiting accounted for more than $38 \%$ of the weight of all organisms caught during the work. No stout whiting were caught during experiment 3 and although both species of whiting were retained during experiments 1 and 2, red spot whiting dominated catches ( $>84 \%$ of the weight of total whiting). In all three experiments, several byproduct species were caught in sufficient numbers to permit analyses, including squid Photololigo spp., calamari Sepioteuthis australis, octopus Octopus spp., cuttlefish Sepeia spp., large-toothed flounder Pseudorhombus arsius, blue swimmer crab Portunus pelagicus, and slipper lobsters Ibacus spp.

\section{Experiment 1: effects of changing mesh size in the trawl body}

No significant differences were detected between the conventional 45 and the new $63 \mathrm{~mm}$ trawl bodies for any of the catches (paried $t$-tests, $P>0.05$ ) (Fig. 4) or the size-frequency distributions of red spot whiting (two-sample Kolmogorov-Smirnov test, $P>0.05$ ) (Fig. 5A).

\section{Experiment 2: effects of a change in mesh con- figuration in the codend}

Compared to the conventional $40 \mathrm{~mm}$ diamond codend, the $41 \mathrm{~mm}$ square codend caught significantly fewer total whiting (mean number and weight reduced by 64 and 54\%, respectively) and total (by 65 and 53\%) and discarded (by 91\%) red spot whiting (paired $t$-tests, $P<0.05$ ) (Fig. 6A and B). No other significant differences were detected between catches, although the $41 \mathrm{~mm}$ square codend did reduce the number and weight of retained whiting by 38 and $45 \%$, respectively (Fig. 6A and B). Two-sample Kolmogorov-Smirnov tests detected significant differences in the relative size-frequency distributions of red spot whiting retained in the diamond- and squaremesh codends, with considerably fewer individuals $<17 \mathrm{~cm}$ TL caught in the latter design (Fig. 5B). 

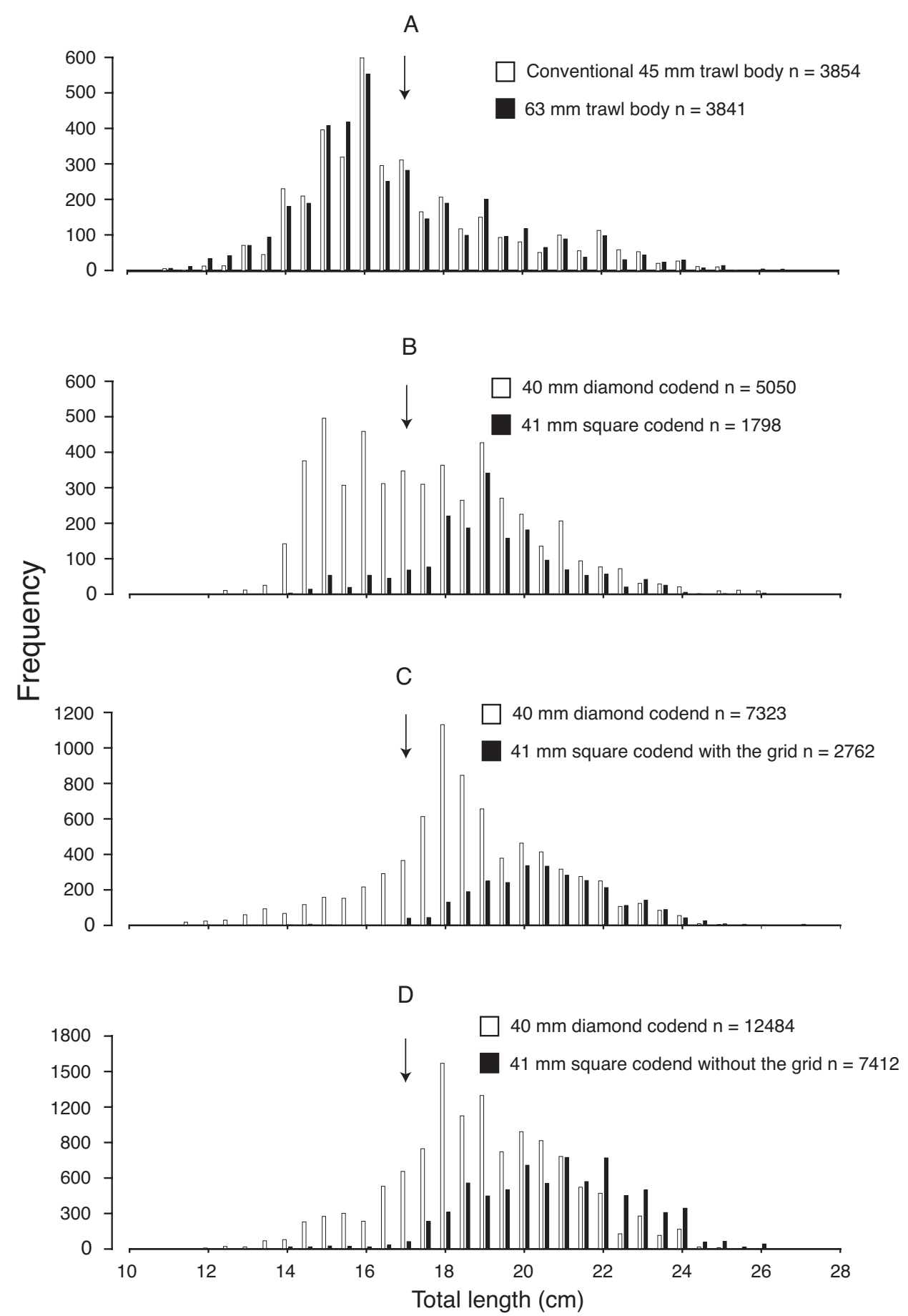

FIG. 5. - Total length-frequency distributions of red spot whiting retained in the conventional gear and the A) $63 \mathrm{~mm}$ trawl body tested in experiment 1, B) $41 \mathrm{~mm}$ square codend tested in experiment 2 and the $41 \mathrm{~mm}$ square codend tested in experiment $3, \mathrm{C})$ with and, D) without the grid attached. The arrows mark the minimum commercial size $(17 \mathrm{~cm} \mathrm{TL})$.

\section{Experiment 3: effects of a separating grid in the extension}

The $41 \mathrm{~mm}$ square codend, with and without the grid installed, caught significantly fewer numbers of total red spot whiting (by 41 and $62 \%$, respectively), numbers (92 and 99\%) and weights (88 and 93\%) of discarded red spot whiting and numbers of octopus (by 48 and 49\%) than the conventional $40 \mathrm{~mm}$ diamond codend (paired $t$-tests, $P<0.05$ ) (Fig. 7A, B and $\mathrm{D}$ ). With the grid installed, the $41 \mathrm{~mm}$ square codend also significantly reduced the weight of total red spot whiting (by 49\%) and the number and weight of retained red spot whiting (by 55 and 44\%) 

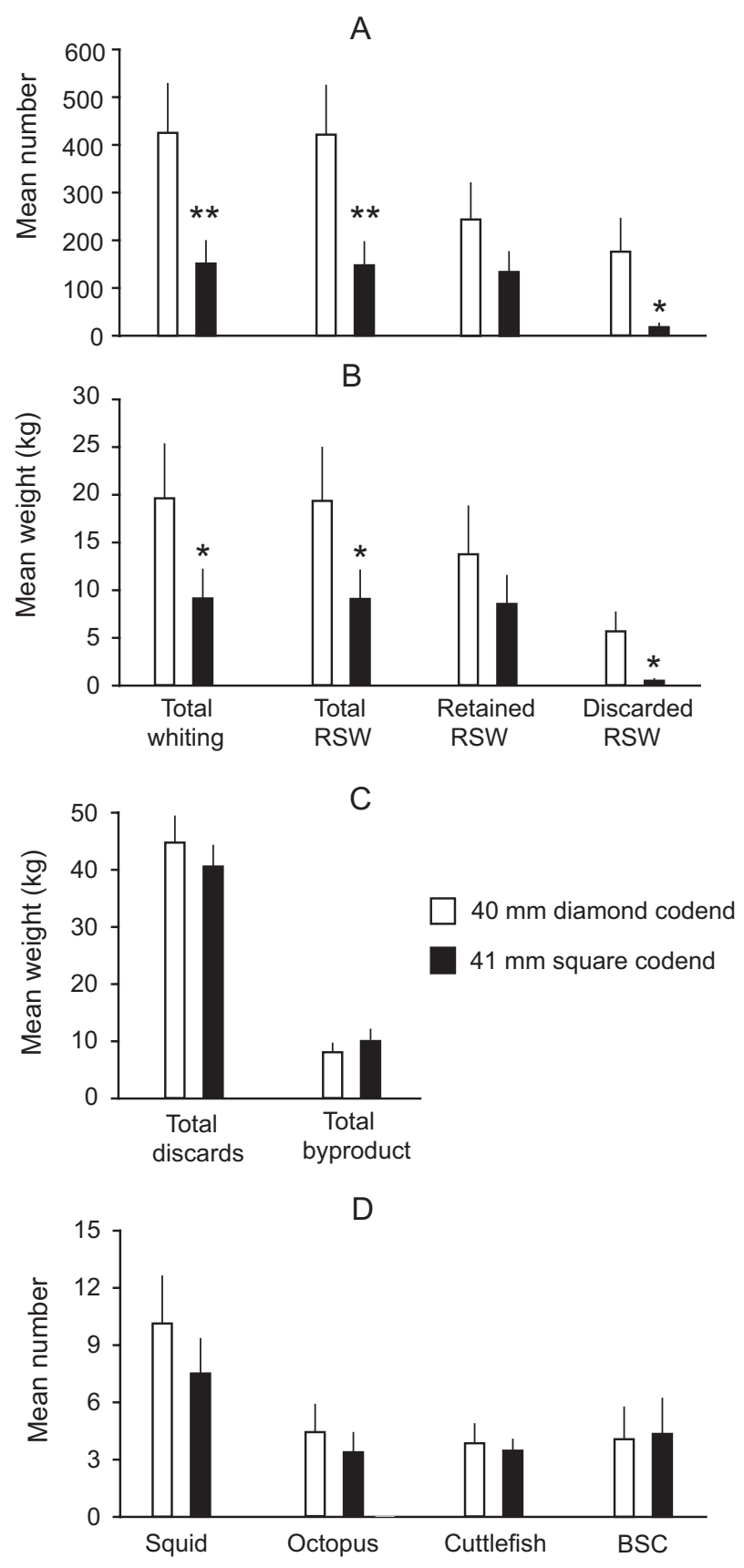

FIG. 6. - Differences in mean catch $(+\mathrm{se})$ per 60 min tow between the conventional $40 \mathrm{~mm}$ diamond and the $41 \mathrm{~mm}$ square codends (same $45 \mathrm{~mm}$ trawl body) for the A) numbers and B) weights of whiting categories, C) weights of total discards and byproduct, and D) numbers of key byproduct species. RSW, red spot whiting; BSC, blue swimmer crab; $* P<0.05, * * P<0.01$ (paired $t$-tests).

(paired $t$-tests, $P<0.05$ ). ANOVA of the differences in all catches between the $41 \mathrm{~mm}$ square codend, with and without the grid installed, and the $40 \mathrm{~mm}$ diamond codend failed to detect any significant influence of the grid (Table 1). Catches of discarded red spot whiting and total discards were significantly different among nights (Table 1). Two-sample Kolmogorov-Smirnov tests detected significant dif-
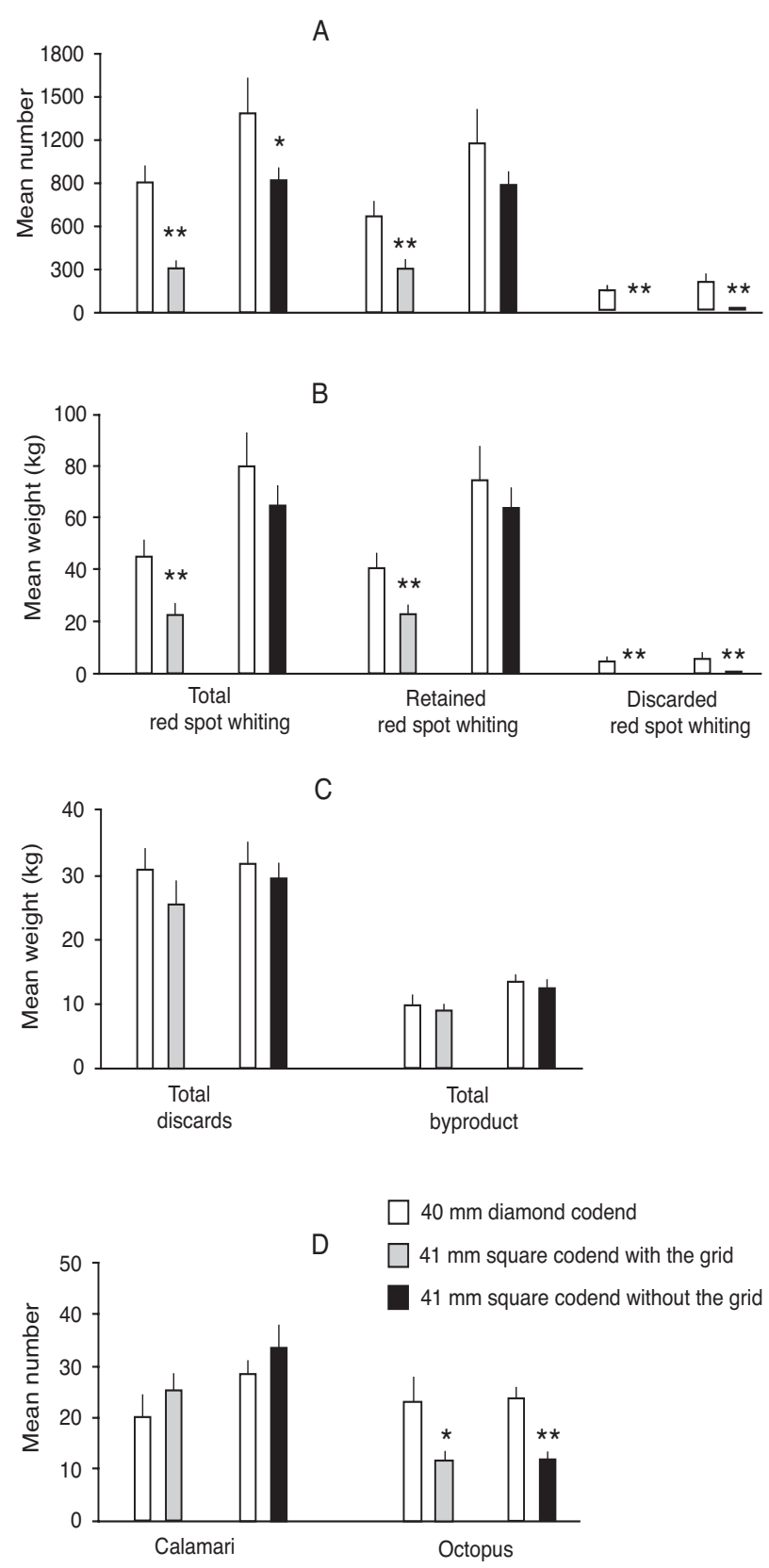

FIG. 7. - Differences in mean catch $(+\mathrm{se})$ per 60 min tow between the conventional $40 \mathrm{~mm}$ diamond codend and the $41 \mathrm{~mm}$ square codends, with and without the grid (same $45 \mathrm{~mm}$ trawl body), for the A) numbers and B) weights of red spot whiting categories, C) weights of total discards and byproduct, and D) numbers of key byproduct species. ${ }^{*} P<0.05$, $* * P<0.01$ (paired $t$-tests).

ferences in the relative size-frequency distributions of red spot whiting between the square-mesh codend, with and without the grid installed in the extension, and between each square-mesh configuration and the $40 \mathrm{~mm}$ diamond codend (Fig. 5C and D). Without the grid installed, the $41 \mathrm{~mm}$ square codend caught more larger-sized ( $>22 \mathrm{~cm}$ TL - Fig. 5D) red spot whiting than either the $41 \mathrm{~mm}$ square codend with the grid or the $40 \mathrm{~mm}$ diamond codend. 
TABLE 1. - Experiment 3: F ratios from two-factor analyses of variance to determine effects on catches due to fishing over 3 different nights with a $45 \mathrm{~mm}$ trawl body attached to a $41 \mathrm{~mm}$ square-mesh codend, with and without a grid in the extension section. All data were $1 \mathrm{n}(\mathrm{x}+$ $10^{2}$ or $\left.10^{3}\right)$ transformed. ** Significant $(P<0.01)$; *Significant $(P<0.05)$; 'pld' indicates that the interaction was non-significant at $P<0.25$ and the sums of squares pooled with the residual.

\begin{tabular}{|c|c|c|c|c|c|c|c|c|c|c|c|}
\hline \multirow{3}{*}{$\begin{array}{l}\text { Treatment } \\
\text { Nights }\end{array}$} & \multirow{3}{*}{$\frac{\mathrm{df}}{1}$} & \multicolumn{2}{|c|}{ Total } & \multicolumn{2}{|c|}{$\begin{array}{l}\text { Red spot whiting } \\
\text { Retained }\end{array}$} & \multicolumn{2}{|c|}{ Discarded } & \multirow{2}{*}{\multicolumn{2}{|c|}{$\begin{array}{c}\text { Total wt of } \\
\text { discards byproduct }\end{array}$}} & \multirow{2}{*}{$\begin{array}{l}\text { No. of } \\
\text { calamari }\end{array}$} & \multirow{2}{*}{$\begin{array}{l}\text { No. of } \\
\text { octopus }\end{array}$} \\
\hline & & $\mathrm{Wt}$ & No. & $\mathrm{Wt}$ & No. & $\mathrm{Wt}$ & No. & & & & \\
\hline & & 0.13 & 1.04 & 0.07 & 0.60 & $4.21 *$ & $7.18 * *$ & $5.32 *$ & 0.69 & 0.12 & 0.40 \\
\hline Grid vs. no grid & 2 & 0.58 & 0.17 & 0.70 & 0.10 & 0.28 & 1.24 & 1.03 & 0.02 & 0.01 & 0.05 \\
\hline Interaction & 2 & $0.11^{\mathrm{pld}}$ & $0.19^{\text {pld }}$ & $0.10^{\text {pld }}$ & $0.44^{\text {pld }}$ & $0.15^{\text {pld }}$ & $0.15^{\mathrm{pld}}$ & $0.10^{\text {pld }}$ & $0.29^{\text {pld }}$ & $0.55^{\text {pld }}$ & $1.32^{\text {pld }}$ \\
\hline Residual & 12 & & & & & & & & & & \\
\hline
\end{tabular}

\section{DISCUSSION}

Of the three modifications examined, changing the orientation of meshes in the codend had the most impact on the selectivity of the trawl. In experiments 2 and 3, compared to the conventional design, the square-mesh codend significantly reduced the catches of discarded $(<17 \mathrm{~cm} \mathrm{TL})$ whiting by between 88 and $99 \%$ which, along with a proportion of smaller commercial sized individuals, contributed towards a reduction in the total catch of between 19 and $64 \%$ (Figs. 6A and B and 7A and B). The escape of whiting through the $41 \mathrm{~mm}$ square mesh is a direct consequence of their morphology in relation to the size of the mesh opening, but was probably augmented by their large abundances and density dependent behavioural responses in the narrow codend. The maximum circumference of the square-mesh codend was $1.23 \mathrm{~m}$ (i.e. 60 bars $\mathrm{x} 20.5 \mathrm{~mm}$ bar length $=1.23 \mathrm{~m}$ ), corresponding to a diameter of $39 \mathrm{~cm}$. Large numbers of fish (e.g. a mean of up to 800 individuals per tow in experiment 3 ) would have been forced to swim in this confined area, which probably upset the balance of the school and initiated escape responses of individual fish towards the sides of the codend (see also Chapman, 1964; Wardle, 1983). The only other commercially important species significantly influenced by the square-mesh codend were octopus during experiment 3 , the numbers of which (owing to their small size relative to the square mesh) were reduced by up to $49 \%$ (Fig. 7D).

Installing a grid in the extension section had considerably less effect on the selection of the trawl. The grid tested during experiment 2 was based on designs that have been used successfully in some penaeid fisheries to mechanically separate and exclude bycatches of macrofauna (e.g. Renaud et al., 1993; Broadhurst, 2000). Large organisms, and especially elasmobranches, are known to co-exist throughout the same areas as both species of whiting and frequently occur in the bycatches of NSW's oceanic trawlers (Kennelly et al., 1998). The absence of any individuals wider than $80 \mathrm{~mm}$ (i.e. the bar spacings in the grid) precluded full assessment of the grid's utility, although there was evidence to suggest that the design requires at least some refinement. Specifically, while the ANOVA failed to detect any effect of the grid (owing to large variability in the magnitudes of differences in catches), the paired comparisons between the conventional trawl and the square-mesh codend, with and without the grid, revealed that there was a greater and significant reduction in total and retained whiting when the grid was used (i.e. by between 44 and 55\%) (Fig. 7A and B). It is possible that, as a result of visual and/or tactile stimuli, some red spot whiting (i) were directed out of the exit hole at the bottom of the grid or, (ii) maintained a position anterior to the grid and then swam back out through the mouth of the trawl during haul back (Watson, 1989). In support of (ii) above, there was a significant difference in the size-frequency distributions of red spot whiting between the $41 \mathrm{~mm}$ square codend, with and without the grid installed: the latter retained fewer large fish (i.e. $>22 \mathrm{~cm}$ TL; Fig. 5C and D). Owing to a superior swimming ability (as a direct function of their size; Bainbridge, 1958), larger fish may have been able to maintain their position in front of the grid during the tow and then swim forward and escape as relative water flow decreased during retrieval. The potential for this effect could be addressed by locating the grid further aft in a longer extension section (thereby increasing the distance between the grid and the trawl mouth), and / or widening the spaces between the bars (to reduce visibility of the grid and allow whiting to more easily pass into the codend). Further, adding more floats to the ventrally located cover would help to ensure that it remains closed during towing (and only opens when large organisms are directed downwards). 
In contrast to the changes discussed above, and unlike related studies with penaeid trawls (e.g. Sumpton et al., 1989; Broadhurst et al., 2000), changing the mesh in the body had no detectable effect on any of the catches examined. Broadhurst $e t$ al. (2000), demonstrated significant and large reductions (i.e. between 24 and 67\%) in the numbers of small individuals of several species of fish and cephalopods, associated with a relatively smaller increase in mesh size (from 45 to $53 \mathrm{~mm}$ ) in the bodies of prawn trawls used in Gulf St Vincent, South Australia. The apparent lack of any active escape by red spot whiting through the $63 \mathrm{~mm}$ trawl body in experiment 1 may be related to species-specific behavioural responses and/or fishery-specific operational characteristics of the gear. Although comparable in terms of their headline and overall length, the trawls used in experiment 1 had a shallower body taper (1N3B) than those used in Gulf St Vincent (1N4B - Broadhurst et al., 1999), and were towed at a slower speed (i.e. 1.2 vs. $1.5 \mathrm{~ms}^{-1}$ ). The combination of these effects (i.e. a greater angle of netting towards a slower relative water flow) may have been sufficient to allow red spot whiting and some of the other small individuals comprising bycatch to be herded away from the sides of the trawl body and into the codend; where most of the selection appears to have occurred.

Irrespective of the mechanisms that contributed to the observed results, the 3 experiments provide a clear direction for future trials to refine whiting trawls. It is apparent that the mesh size in the trawl body could be increased to at least $63 \mathrm{~mm}$. The corresponding reduction in twine area would reduce drag on the triple-rigged trawls and probably save fuel. For some operators, a reduction in drag could facilitate a faster towing speed and possibly concomitant increases in the catches of some species, including whiting. But, given the results presented here, it is likely that any increase in unwanted catches of small whiting would be mitigated via the use of appropriate sized, square-shaped mesh (i.e. approaching $20 \mathrm{~mm}$ bar length) in the codend.

The commercial use of square-mesh codends by trawlers targeting whiting has the potential to guard against recruitment overfishing of stocks. Despite their large abundances in the bycatches of NSW trawlers and their commercial importance (Kennelly et al., 1998), very little data are available on the biology of either species off eastern Australia. Using fish collected from Botany Bay, Burchmore et al., (1986), proposed that sexual maturity occurs at 14 $\mathrm{cm}$ fork length - FL ( $15 \mathrm{~cm}$ TL) in both sexes of red spot whiting and at 17 and $18 \mathrm{~cm}$ FL (17.8 and 18.9 $\mathrm{cm}$ TL, respectively) in male and female stout whiting. In contrast, Hyndes and Potter (1996) observed that $50 \%$ of male and female stout whiting off south western Australia reached sexual maturity at 12 and $12.3 \mathrm{~cm}$ TL, respectively, and that this occurred within the first year of life. Regardless of these differences, the $41 \mathrm{~mm}$ square codend would apparently allow the majority of maturing individuals to escape.

While the fate of these escaping fish was not assessed as part of this study, previous work has demonstrated that the mortality rates of fish attributed to stress incurred during capture and escape from trawls are relatively low compared to the numbers surviving (e.g. Main and Sangster, 1990; Soldal et al., 1993; Turunen et al., 1994; Broadhurst et al., 1997). Of particular relevance, another species of whiting, Sillago ciliata was demonstrated to sustain $<4 \%$ scale loss and 3\% mortalities over 30 days after being fatigued to exhaustion and forced to pass through square meshes in the laboratory (Broadhurst et al., 1997). Assuming similar, low mortality by escaping red spot and stout whiting, square-mesh codends could positively benefit stocks and, in the absence of more detailed life history information, the adoption of square mesh by whiting trawlers seems an appropriate, precautionary management strategy.

\section{ACKNOWLEDGEMENTS}

This work was funded by the NSW Department of Primary Industries. Thanks are extended to Reg, Helen and Greg Parker for the use of their vessels and to Jock Sutherland, Koen Dykstra, Marcus Millar, Paul Butcher and Daniel Johnson for technical assistance.

\section{REFERENCES}

Alverson, D.L., M.H. Freeberg, S.A. Murawski and J.G. Pope. 1994. A global assessment of fisheries bycatch and discards. FAO Fish. Tech. Pap., 339: 1-233.

Andrew, N.L. and J.G. Pepperell. - 1992. The by-catch of shrimp trawl fisheries. Oceanogr. Mar. Biol. Ann. Rev., 30: 527-565.

Bainbridge, R. - 1958. The speed of swimming of fish as related to size and to the frequency and amplitude of the tailbeat. J. Exp. Biol., 35: 109-133.

Broadhurst, M.K. - 2000. Modifications to reduce bycatch in prawn trawls: A review and framework for development. Rev. Fish Biol. Fish., 10: 27-60.

Broadhurst, M.K. and S.J. Kennelly. - 1996. Effects of the circum- 
ference of codends and a new design of square-mesh panel in reducing unwanted by-catch in the New South Wales oceanic prawn-trawl fishery, Australia. Fish. Res., 27: 203-214.

Broadhurst, M.K. and S.J. Kennelly. - 1997. The composite squaremesh panel: a modification to codends for reducing unwanted bycatch and increasing catches of prawns throughout the New South Wales oceanic prawn-trawl fishery. Fish. Bull., 95: 653664.

Broadhurst, M.K., S.J. Kennelly and D.T. Barker. - 1997. Simulated escape of juvenile sand whiting (Sillago ciliata) through square-meshes: effects on scale-loss and survival. Fish. Res., 32: $51-60$.

Broadhurst, M.K., R.B. Larsen, S.J. Kennelly and P.E. McShane. 1999. Use and success of composite square-mesh codends in reducing bycatch and in improving size-selectivity of prawns in Gulf St Vincent, South Australia. Fish. Bull., 97: 434-448.

Broadhurst, M.K., P.E. McShane and R.B. Larsen. - 2000. Effects of twine diameter and mesh size in the body of prawn trawls on bycatch in Gulf St. Vincent, Australia. Fish. Bull., 98: 463-473.

Burchmore, J.J., D.A. Pollard, M.J. Middleton, J.D. Bell and B.C. Pease. - 1988. Biology of four species of whiting (Pisces: Sillaginidae) in Botany Bay, New South Wales. Aust. J. Mar. Freshwater Res., 39: 709-727.

Chapman, C.J. - 1964. Importance of mechanical stimuli in fish behaviour, especially to trawls. In: Modern Fishing Gear of the World, Vol 2, pp. 537-540. Fishing News Books, London.

Hyndes, G.A. and I.C. Potter. - 1996. Comparisons between the age structures, growth and reproductive biology of two co-occurring sillaginids, Sillago robusta and S. bassensis, in temperate coastal waters of Australia. J. Fish. Biol., 49: 14-32.

Kennelly, S.J., K.J. Graham, S.S. Montgomery, N.L. Andrew and P.A. Brett. - 1993. Variance and cost-benefit analyses to deter- mine optimal duration of tows and levels of replication for sampling relative abundances of species using demersal trawling. Fish. Res., 16: 51-67.

Kennelly, S.J., G.W. Liggins and M.K. Broadhurst. - 1998. Retained and discarded by-catch from oceanic prawn trawling in New South Wales, Australia. Fish. Res., 36: 217-236.

Main, J. and G.I. Sangster. - 1990. An assessment of the scale damage to and survival rates of young gadoid fish escaping from the codend of a demersal trawl. Scottish Fisheries Research Report No. 46. pp. 28.

Renaud, M., G. Gitschlag, E. Klima, A. Shah, D. Koi, and J. Nance. - 1993. Loss of shrimp by turtle excluder devices (TEDs) in coastal waters of the United States, North Carolina to Texas: March 1988 - August 1990. Fish. Bull., 91: 129-137.

Soldal, A.V., A. Engàs and B. Isaksen. - 1993. Survival of gadoids that escape from a demersal trawl. ICES Mar. Sci. Symp., 196: 122-127.

Sumpton, W.D., P.J. Smith and B.G. Robotham. - 1989. The influence on catch of monofilament and multifilament netting in otter prawn-trawls. Fish. Res., 8: 35-44.

Turunen, T., A. Kakela and H. Hyvarinen. - 1994. Trawling stress and mortality in undersized $(<40 \mathrm{~cm})$ brown trout (Salmo trutta). Fish. Res., 19: 51-64.

Wardle, C.S. -1983 . Fish reactions to towed fishing gears. In: A. MacDonald and I.G. Priede (eds.), Experimental biology at sea, pp. 167-195. New York: Academic Press.

Watson. J. - 1989. Fish behavior and trawl design: Potential for selective trawl development. In: C.M. Campbell (ed.), Proceedings of the world symposium on fishing gear and fishing vessels, pp. 25-29. Marine Institute, St Johns, Canada.

Scient. ed.: G. Pequeño 
